\title{
KEEFEKTIFAN PENGGUNAAN GOOGLE CLASSROOM DALAM PEMBELAJARAN DARING SELAMA PANDEMI COVID-19 PADA PROGRAM STUDI S1 PENDIDIKAN ADMINISTRASI PERKANTORAN UNIVERSITAS NEGERI SURABAYA
}

\author{
Ruri Nurul Aeni Wulandari ${ }^{1 \%}$, Lifa Farida Panduwinata ${ }^{1)}$ \\ Prodi Pendidikan Administrasi Perkantoran, Fakultas Ekonomi, Universitas Negeri Surabaya \\ *Email:ruriwulandari@unesa.ac.id
}

\begin{abstract}
The purpose of this study was to determine the effectiveness of using Google Classroom in online learning during the Covid-19 pandemic. The method used in this research is descriptive quantitative. The research sample was students of the Office Administration Education Study Program at the State University of Surabaya, batch 2017, 2018, and 2019, which means 95 people. The data was collected using a questionnaire, while the data analysis technique used a percentage. The results showed that Google Classroom was effectively applied in online learning during the Covid-19 pandemic.
\end{abstract}

Keywords: Google Classroom, online course, virtual class

\begin{abstract}
Abstrak
Penelitian ini bertujuan untuk mengetahui keefektifan penggunaan Google Classroom dalam pembelajaran daring selama pandemi Covid-19. Metode yang digunakan dalam penelitian ini adalah deskriptif kuantitatif. Sampel penelitian adalah mahasiswa Program Studi S-1 Pendidikan Administrasi Perkantoran di Universitas Negeri Surabaya angkatan tahun 2017, 2018, dan 2019 yang berjumlah 95 orang. Pengumpulan data dilakukan menggunakan kuesioner, sedangkan teknik analisis data menggunakan persentase. Hasil penelitian menunjukkan bahwa Google Classroom efektif diterapkan dalam pembelajaran daring selama pandemi Covid-19.
\end{abstract}

Kata kunci: Google Classroom, pembelajaran daring, kelas virtual 


\section{PENDAHULUAN}

Pandemi Covid-19 yang kini sedang melanda dunia berdampak tidak hanya pada sektor ekonomi, tetapi juga pada sektor pendidikan khususnya pendidikan tinggi. Demi mencegah penularan virus secara lebih meluas, pemerintah Indonesia melalui Kementerian Pendidikan dan Kebudayaan Direktorat Pendidikan Tinggi mengeluarkan surat edaran Nomor 1 Tahun 2020 tentang Pencegahan Penyebaran Covid-19 di Perguruan Tinggi yang mendorong perguruan tinggi supaya menyelenggarakan proses belajar mengajar dari rumah secara daring, atau yang lebih dikenal sebagai pembelajaran jarak jauh (PJJ) (Kemdikbud, 2020). Perguruan tinggi pun dengan cepat menyikapi instruksi tersebut (Firman \& Rahman, 2020), termasuk Universitas Negeri Surabaya yang melaksanakan pembelajaran daring dengan menggunakan aplikasi pembelajaran maupun kelas virtual untuk mencegah penyebaran Covid-19 di lingkungan Unesa.

Pembelajaran daring merupakan proses pembelajaran yang memanfaatkan jaringan internet dengan aksesibilitas, konektivitas, fleksibilitas, dan kemampuan untuk menciptakan berbagai interaksi pembelajaran (Ahmad, 2020; Moore, Dickson-Deane, \& Galyen, 2011). Prinsip dari pembelajaran secara daring adalah peserta didik bisa mengakses materi beserta sumber pembelajaran tanpa batasan waktu dan tempat (Ahmad, Nuzula, \& Makky, 2020) namun tetap memperhatikan capaian tujuan pembelajaran (Kurniasari et al., 2020). Oleh sebab itu, dosen sebagai pengajar memerlukan strategi, metode pengajaran, dan perangkat pembelajaran yang sesuai untuk program pembelajaran jarak jauh terutama di masa pandemi seperti saat ini. Berbagai platform pembelajaran daring yang dapat dimanfaatkan oleh dosen antara lain seperti Google Classroom, Google Meet, Zoom, Whatsapp, dan lain-lain (Abidin, Hudaya, \& Anjani, 2020; Mustakim, 2020; Okmawati, 2020).

Google Classroom menjadi salah satu platform pembelajaran daring yang populer dan banyak digunakan sejak diluncurkan oleh Google pada tahun 2014 (Albashtawi \& Bataineh, 2020; Al-maroof \& Al-emran, 2018; Azhar \& Iqbal, 2018). Google Classroom merupakan alat digital yang memungkinkan siswa untuk menghadiri kelas online (Hussaini et al., 2020). Google Classroom merupakan Learning Management System (LMS) yang terpadu dengan produk Google lainnya seperti Gmail, Drive, Hangout, Meet, YouTube, dan Calendar (Henukh, Rosdianto, \& Oikawa, 2020; Islam, 2019). Google Classroom memungkinkan para pengajar menciptakan ruang kelas di dunia maya yang berfungsi sebagai sarana untuk pembagian tugas, penyerahan tugas, dan penilaian dengan cara tanpa kertas (Alim et al., 2019).

Mai (2019) mengungkapkan bahwa ada banyak manfaat yang ditawarkan oleh Google Classroom. Pertama, Google Classroom dapat diakses secara gratis melalui ponsel, PC, laptop, atau tablet (Hanifah \& Putri, 2020). Kedua, mendukung interaksi dua arah antara pengajar dan peserta didik, dan di antara peserta didik (Laili \& Muflihah, 2020). Ketiga, semua pihak dapat berbagi dan mengakses sumber materi, serta ber-kontribusi pada konten dokumen (Okmawati, 2020). Semua pemberitahuan akan dikirim ke alamat $e$-mail pengguna, sehingga tidak ada pesan atau pengumuman yang terlewat (Alim et al., 2019). Tidak hanya itu, Google Clasroom juga ramah pengguna sehingga mahasiswa dan dosen tidak akan mengalami kesulitan dalam mengoperasikannya (Mai, 2019). 
Ruri Nurul Aeni Wulandari, Lifa Farida

Sebagai media pembelajaran, Google
room telah mendukung kesuksesan dalam Classroom telah mendukung kesuksesan dalam
belajar mengajar karena dapat diintegrasikan dengan berbagai model atau metode (Henukh et al., 2020). Sehingga melalui Google Classroom, diasumsikan bahwa tujuan pembelajaran akan lebih mudah terwujud dan penuh makna (Hanifah \& Putri, 2020). Beberapa penelitian menemukan bahwa Google Classroom sangat membantu dan efektif dalam memfasilitasi proses pembelajaran (Albashtawi \& Bataineh, 2020; Okmawati, 2020; Bute, 2020; Alim et al., 2019; Mai, 2019). Lebih lanjut, hasil penelitian Fauzan \& Arifin (2019) menemukan bahwa penggunaan Google Classroom efektif dalam meningkatkan hasil belajar mahasiswa UIN Syarif Hidayatullah Jakarta.

Dengan situasi global pandemi Covid-19 yang membatasi ruang gerak dan sosial saat ini, maka Google Classroom direkomendasikan untuk digunakan karena platform ini akan membantu baik mahasiswa maupun guru agar tetap saling terhubung, bekerja sama, membuat dan menyelesaikan tugas, melakukan penilaian, serta membagikan catatan perkuliahan (Hussaini et al., 2020). Hasil penelitian Permata \& Bhakti (2020) turut mendukung temuan bahwa Google Classroom efektif digunakan dalam pembelajaran virtual karena siswa merasa mudah dalam penggunaanya, juga dari segi tampilan dan akses pengumuman, materi, serta tugas yang lebih efisien.

Berdasarkan kajian literatur yang telah paparkan menyatakan bahwasanya Google Classroom efektif dalam meningkatkan kegiatan belajar mengajar. Akan tetapi, studi empiris yang yang mengeksplorasi tentang keefektifan penerapan Google Classroom dalam kegiatan pembelajaran daring di perguruan tinggi di Indonesia masih terbatas, khususnya pada Program Studi Pendidikan Administrasi
Perkantoran. Karena itu, penelitian ini dilakukan untuk mengetahui keefektifan penggunaan Google Classroom dalam pembelajaran daring selama pandemi Covid-19 pada mahasiswa Program Studi S-1 Pendidikan Administrasi Perkantoran di Universitas Negeri Surabaya.

\section{METODE PENELITIAN}

Metode yang digunakan dalam penelitian ini adalah deskriptif kuantitatif. Sampel penelitian adalah mahasiswa Program Studi S-1 Pendidikan Administrasi Perkantoran di Universitas Negeri Surabaya angkatan tahun 2017, 2018, dan 2019 yang berjumlah 95 orang. Pengumpulan data dilakukan menggunakan kuesioner daring berupa tautan link Google Form yang dibagikan kepada mahasiswa. Kuesioner disusun menurut skala Likert yang terdiri dari 11 pertanyaan dengan empat alternatif jawaban, yaitu 1 (sangat tidak setuju) hingga 4 (sangat setuju). Sementara teknik analisis data yang digunakan adalah persentase.

Sebelum kuesioner dibagikan kepada mahasiswa, instrumen terlebih dahulu direview oleh para ahli dari bidang pembelajaran demi memastikan validitas isinya. Instrumen lalu dimodifikasi berdasarkan saran dari para ahli tersebut. Selanjutnya, uji reliabilitas dilakukan untuk memastikan keandalan instrumen dengan melibatkan 30 orang mahasiswa yang mengikuti pembelajaran daring. Hasil Cronbach Alpha sebesar 0,88 menunjukkan bahwa instrumen reliabel dan dapat digunakan untuk pengambilan data penelitian.

\section{HASIL DAN PEMBAHASAN}

Berdasarkan hasil survei pada Gambar 1, terlihat bahwa mahasiswa Program Studi S-1 Administrasi Perkantoran Universitas Negeri 
Ruri Nurul Aeni Wulandari, Lifa Farida Panduwinata, Keefektifan Penggunaan Google Classroom $\mid 4$

Surabaya didominasi oleh perempuan dengan persentase sebesar $90 \%$, sedangkan responden laki-laki hanya sebesar $10 \%$.

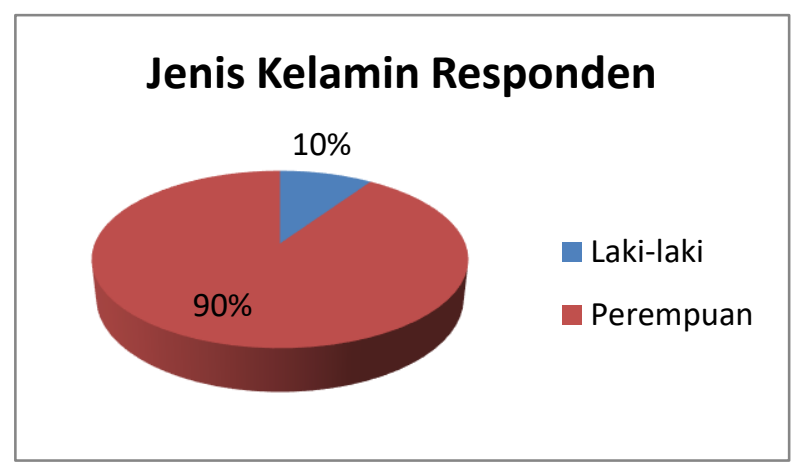

Gambar 1. Persentase Jenis Kelamin Responden

Setelah dilakukan penelitian dan analisis data dengan menggunakan metode persentase, maka hasil penelitian tersebut disajikan pada Gambar 2 berikut ini.

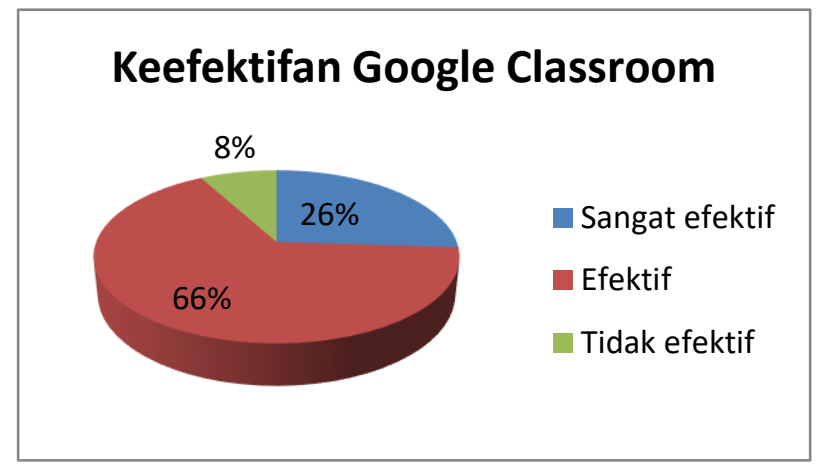

Gambar 2. Persentase Keefektifan

Google Classroom

Berdasarkan hasil analisis pada Gambar 2, diketahui bahwa terdapat $66 \%$ atau sebanyak 62 orang mahasiswa menyatakan bahwa penggunaan Google Classroom dalam pembelajaran daring selama pandemi Covid-19 sudah efektif, sedangkan sisanya sebesar $26 \%$ atau sebanyak 25 mahasiswa menyatakan penggunaan Google Classroom sangat efektif, dan $8 \%$ atau sebanyak 8 mahasiswa menyatakan tidak efektif.
Pada Tabel 1 di bawah ini disajikan respon mahasiswa terkait keefektifan Google Classroom.

Tabel 1. Respon Mahasiswa terhadap Keefektifan Penggunaan Google Classroom

\begin{tabular}{lccc}
\hline \multicolumn{2}{c}{ Item } & Mean & $\begin{array}{l}\text { Std. } \\
\text { Dev }\end{array}$ \\
\hline $\begin{array}{l}\text { Tools yang ada di Google } \\
\text { Classroom membantu saya lebih }\end{array}$ & 3,21 & 0,48 \\
$\begin{array}{l}\text { mudah dalam mengikuti } \\
\text { perkuliahan }\end{array}$ & & \\
Dosen menyampaikan kata kunci & 2,89 & 0,54
\end{tabular}

Dosen menyampaikan kata kunci atau clue terkait materi yang akan dibahas

Saya paham terkait materi dan informasi yang disampaikan dosen melalui Google Classroom Materi perkuliahan yang dibahas, sesuai dengan rencana perkuliahan sebelumnya

Adanya deadline di tugas Google Classroom membantu saya untuk mengerjakan dan mengumpulkan tugas tepat waktu

Dosen membuat peserta perkuliahan terlibat dan berpartisipasi aktif dalam diskusi produktif

Dosen ramah dan mudah dihubungi selama kegiatan pembelajaran

Saya merasa nyaman berbicara dan berinteraksi dengan peserta lain dalam kegiatan pembelajaran melalui Google Classroom

Sudut pandang saya diakui oleh peserta lain selama kegiatan pembelajaran

Pembelajaran dilaksanakan sesuai dengan jadwal perkuliahan

$3,15 \quad 0,44$

$3,26 \quad 0,57$

$3,23 \quad 0,56$

$3,31 \quad 0,49$

$3,35 \quad 0,58$

$3,39 \quad 0,57$

$3,02 \quad 0,60$

$2,94 \quad 0,71$ yang disepakati oleh mahasiswa dan dosen

Saya sangat antusias dalam 3,09 0,46 mengikuti pembelajaran melalui Google Classroom

Pada Tabel 1 menunjukkan bahwa secara keseluruhan mahasiswa memberikan respon 
positif terhadap penggunaan Google Classroom. Skor mean tertinggi adalah saya merasa nyaman berbicara dan berinteraksi dengan peserta lain dalam kegiatan pembelajaran melalui Google Classroom dengan perolehan nilai mean sebesar 3,39. Hasil tersebut menunjukkan mahasiswa sangat setuju bahwa Google Classroom membuat komunikasi dan interaksi mereka dengan peserta lainnya di dunia maya menjadi lebih nyaman selama kegiatan pembelajaran daring. Sedangkan nilai mean terendah adalah dosen menyampaikan kata kunci atau clue terkait materi yang akan dibahas dengan nilai mean sebesar 2,89. Hasil ini menunjukkan bahwa rata-rata responden tidak setuju bahwa dosen menyampaikan kata kunci atau clue terkait materi yang akan dibahas. Oleh sebab itu, dosen harus memberikan arahan yang jelas sehingga mahasiswa bisa memahami materi apa saja yang akan dipelajari saat kegiatan pembelajaran daring menggunakan Google Classroom.

Secara persentase seperti yang tampak pada Gambar 1, dapat disimpulkan bahwa mayoritas mahasiwa Program Studi S-1 Administrasi Perkantoran menyetujui bahwa Google Classroom efektif diterapkan dalam pembelajaran daring selama pandemi Covid-19. Hasil temuan penelitian ini sejalan dengan penelitian sebelumnya, di antaranya Hanifah \& Putri (2020) yang menunjukkan bahwa Google Classroom efektif digunakan sebagai media pembelajaran bagi dosen untuk menyampaikan informasi dan materi perkuliahan.

Dalam pembelajaran daring menggunakan media Google Classroom, dosen secara keseluruhan berperan sebagai fasilitator di kelas (Islam, 2019). Saat pembelajaran daring melalui Google Classroom, mahasiswa dapat mempelajari materi pelajaran dan menyelesaikan tugas yang diberikan sesuai dengan tenggat waktu penyerahan tugas. Jika mahasiswa menemukan kesulitan saat mempelajari materi pelajaran, mereka menuliskan masalah tersebut di kolom komentar dan dosen akan mencoba menjawab semua pertanyaan. Hussaini et al. (2020) mengemukakan bahwa Google Classroom efektif dalam meningkatkan akses dan perhatian mahasiswa terhadap pembelajaran, dimana pengetahuan dan keterampilan yang diperoleh melalui Google Classroom membuat mahaiswa menjadi pembelajar yang aktif.

Hasil temuan dalam penelitian ini juga didukung oleh Okmawati (2020) yang menyatakan bahwa penggunaan Google Classroom selama pandemi efektif dan bermanfaat untuk meningkatkan keterampilan, kedisiplinan siswa, serta memenuhi tuntutan pemerintah untuk terus melanjutkan proses belajar mengajar. Google Classroom adalah pilihan terbaik untuk membantu siswa agar lebih memahami subjek serta menyelesaikan silabus tepat waktu (Bute, 2020). Beberapa penelitian lainnya menemukan bahwa mahasiswa merasa puas terhadap kegiatan pembelajaran di Google Classrom (Cristiano \& Triana, 2019; Shaharanee, Jamil, \& Rodzi, 2016). Dengan demikian, menggunakan Google Classroom pembelajaran akan membuat kegiatan belajar mengajar menjadi lebih efektif, sebab dosen dan mahasiswa dapat bertatap muka kapan saja melalui kelas daring Google Classroom (Henukh et al., 2020).

\section{PENUTUP}

\section{Simpulan}

Berdasarkan hasil penelitian dan pembahasan yang telah dipaparkan dapat disimpulkan bahwa Google Classroom efektif 
Ruri Nurul Aeni Wulandari, Lifa Farida
pembelajaran daring selama pandemi Covid-19. Dalam menyikapi merebaknya pandemi Covid-19, pemerintah membuat kebijakan yang menuntut seluruh aktivitas manusia, termasuk bidang pendidikan tinggi agar dilakukan secara daring. Google Classroom dapat menjadi salah satu pilihan media alternatif bagi dosen untuk menghadirkan kegiatan pembelajaran daring yang menarik bagi peserta didik di masa pandemi.

\section{Saran}

Berdasarkan hasil analisis, terdapat item yang memperoleh skor terendah yaitu pada item dosen menyampaikan kata kunci atau clue terkait materi yang akan dibahas. Dengan demikian, dosen diharapkan agar dapat menyampaikan instruksi yang lebih jelas tentang materi apa saja yang akan dipelajari dan bagaimana mengikuti kegiatan pembelajaran menggunakan Google Classroom sehingga diharapkan kegiatan pembelajaran daring selama pandemi Covid-19 dapat terlaksana dengan lebih optimal. Sementara untuk penelitian selanjutnya, sebaiknya dilakukan dengan ukuran sampel yang lebih besar dan dalam konteks yang berbeda seperti mempertimbangkan persepsi dosen terhadap efektivitas penggunaan Google Classroom sebagai media pembelajaran. Selain itu, metode penelitian juga dapat menggabungkan antara data kuantitatif dan kualitatif.

\section{DAFTAR PUSTAKA}

Abidin, Z., Hudaya, A., \& Anjani, D. (2020). Efektivitas pembelajaran jarak jauh pada masa pandemi covid-19. Research and Development Journal of Education, (Special Edition), 131-146.

Ahmad, Nuzula, F., \& Makky, K. (2020). Efektivitas pembelajaran daring dengan menggunakan google classroom pada mata pelajaran matematika di Madrasah Aliyah Darul Falah Batu Jangkih. EL-HIKAM: Jurnal Pendidikan dan Kajian Keislaman, 1(1), 66-82.

Ahmad, I. F. (2020). Alternative assessment in distance learning in emergencies spread of coronavirus disease (Covid-19) in Indonesia. Jurnal Pedagogik, 07(01), 195222.

Albashtawi, A. H., \& Bataineh, B. K. Al. (2020). The effectiveness of google classroom among EFL Students in Jordan: An Innovative Teaching and Learning Online Platform. iJET, 15(11), 78-88. Retrieved from https://doi.org/10.3991/ijet.v15i11.12865 Abeer

Alim, N., Linda, W., Gunawan, F., \& Saad, M. S. (2019). The effectiveness of google classroom as an instructional media: A case of State Islamic Institute of Kendari, Indonesia. Humanities \& Social Sciences Reviews, 7(2), 240-246. Retrieved from https://doi.org/10.18510/hssr.2019.7227

Al-maroof, R. A. S., \& Al-emran, M. (2018). Students acceptance of google classroom: an exploratory study using PLS-SEM approach. I-JET, 13(6), 112-123.

Azhar, K. A., \& Iqbal, N. (2018). Effectiveness of google classroom: Teachers' perceptions. Prizren Social Science Journal, 2(2), 52-66.

Bute, A. (2020). Google classroom: A subtitute to classroom teaching in engineering colleges. Research Journal of English Language and Literature (RJELAL), 8(2), 240-244. https://doi.org/10.33329/rjelal.8.2.240

Cristiano, K. L., \& Triana, D. A. (2019). Google classroom as a tool-mediated for learning. Journal of Physics: Conference Series, 1161, 1-4. https://doi.org/10.1088/1742$6596 / 1161 / 1 / 012020$ 
Ruri Nurul Aeni Wulandari, Lifa Farid
Fauzan, \& Arifin, F. (2019). The effectiveness
of google classroom media on the students learning outcomes of Madrasah Ibtidaiyah Teacher Education Department. Al Ibtida: Jurnal Pendidikan Guru MI, 6(2), 271285.

Firman, \& Rahman, S. R. (2020). Pembelajaran online di tengah pandemi Covid-19. Indonesian Journal of Educational Science (IJES), 02(02), 81-89.

Hanifah, W., \& Putri, K. Y. S. (2020). Efektivitas komunikasi google classroom sebagai media pembelajaran jarak jauh pada mahasiswa Ilmu Komunikasi Universitas Negeri Jakarta angkatan 2018. MEDIALOG: Jurnal Ilmu Komunikasi, 3(2), 24-35.

Henukh, A., Rosdianto, H., \& Oikawa, S. (2020). Implementation of google classroom as multimedia learning. Jurnal Ilmu Pendidikan Fisika, 5(1), 38-44. https://doi.org/10.26737/jipf.v5i1.1539

Hussaini, I., Ibrahim, S., Wali, B., Libata, I., \& Musa, U. (2020). Effectiveness of google classroom as a digital tool in teaching and learning: Students' perceptions. International Journal of Research and Innovation in Social Science, 4(4), 3-7.

Islam, M. S. (2019). Bangladesh University students' perception on using google classroom for teaching english. International Journal of PsychoEducational Sciences, 8(2), 57-65.

Kemdikbud. Surat Edaran Nomor 1 Tahun 2020 tentang Pencegahan Penyebaran Corona Virus Disease (Covid-19) di Perguruan Tinggi, Kementrian Pendidikan dan Kebudayaan (2020). Indonesia: Kementerian Pendidikan dan Kebudayaan Direktorat Jenderal Pendidikan Tinggi. Retrieved from http://kemdikbud.go.id/main/?lang=id

Kurniasari, A., Pribowo, F. S. P., \& Putra, D. A. (2020). Analisis efektivitas pelaksanaan belajar dari rumah (BDR) selama pandemi Covid-19. Jurnal Review Pendidikan Dasar: Jurnal Kajian Pendidikan Dan Hasil Penelitian, 6(3), 1-8.

Laili, E. N., \& Muflihah, T. (2020). The effectiveness of google classroom in teaching writing of recount text for senior high schools. Journal of Languages and Language Teaching, 8(4), 348-359. Retrieved from https://doi.org/10.33394/jollt.v\%vi\%i.2929

Mai, T. T. (2019). Evaluating google classroom in teaching and learning writing at Ho Chi Minh City University of Technology. GEN TEFL Journal, 4(December), 1-11.

Moore, J. L., Dickson-Deane, C., \& Galyen, K. (2011). E-Learning, online learning, and distance learning environments: Are they the same? The Internet and Higher Education, 14(2), 129-135. Retrieved from https://doi.org/10.1016/j.iheduc.2010.10.00 1

Mustakim. (2020). Efektivitas pembelajaran daring menggunakan media online selama pandemi Covid-19 pada mata pelajaran matematika. Al Asma: Journal of Islamic Education, 2(1), 1-12.

Okmawati, M. (2020). The use of google classroom during pandemic. Journal of English Language Teaching, 9(2), 438443.

Permata, A., \& Bhakti, Y. B. (2020). Keefektifan virtual class dengan google classroom dalam pembelajaran fisika dimasa pandemi Covid-19. Jurnal Inovasi Pendidikan Fisika Dan Riset Ilmiah, 4(1), 27-33.

Shaharanee, I. N. M., Jamil, J. M., \& Rodzi, S. S. M. (2016). The Application of google classroom as a tool for teaching and learning. Journal of Telecommunication, Electronic and Computer Engineering, 8(10), 8-11. 